\title{
The Impact of Hydrocarbon Pollution on Soil Degradation Using GIS Techniques and Soil Characterization in Burgan Oil field, South Kuwait
}

\author{
H. D. Mostagab1', M. Senosy², A. Al Rashed' ${ }^{3}$, M. Essam Salem ${ }^{4}$ \\ ${ }^{1}$ AIghanim Int'l Co., Ahmadi city, Kuwait \\ ${ }^{2}$ Applied Geophysics, Geology Department, Assiut University, Assiut, Egypt \\ ${ }^{3}$ Paeat.ku, College of Basic Education, Kuwait city, Kuwait \\ ${ }^{4}$ Sedimentology, Geo Department, Assiut University, Assiut, Egypt \\ Email: Hossam.mostagab@gmail.com,mmsenosy@yahoo.com, ahmedbufarsan@gmail.com, maessa2002@yahoo.com
}

How to cite this paper: Mostagab, H.D., Senosy, M., Al Rashed, A. and Salem, M.E. (2018) The Impact of Hydrocarbon Pollution on Soil Degradation Using GIS Techniques and Soil Characterization in Burgan Oil field, South Kuwait. Journal of Environmental Protection, 9, 699-719.

https://doi.org/10.4236/jep.2018.96044

Received: March 13, 2018

Accepted: May 28, 2018

Published: May 31, 2018

Copyright $\odot 2018$ by authors and Scientific Research Publishing Inc. This work is licensed under the Creative Commons Attribution International License (CC BY 4.0).

http://creativecommons.org/licenses/by/4.0/

(c) (i) Open Access

\begin{abstract}
Understanding the complex spatio-temporal relationships between environmental pollution and disease and identifying exposures to environmental hazards in high-risk populations are essential elements of an effective environmental and public health management program. Modern computer technologies, such as geographic information systems (GIS), provide cost-effective tools for evaluating interventions and policies potentially affecting health outcomes. Military activities during the occupation and subsequent liberation war at 1991 caused direct and indirect damage to Kuwait's environment and ecosystems. Geographic Information Systems (GIS) provide a powerful tool in managing and analyzing spatial data. It has been applied successfully to large variety of fields, one field of particular interest is the field of disaster identification and mitigation represent in the impact of hydrocarbon pollution on soil degradation in Burgan oil field, South Kuwait. It is well understood that hazard identification and land management play a major part in the reducing the impact of natural disasters. This is a role GIS is well suited to especially when combined with field investigation work. This study highlights the high level achievements of the environmental assessment for the oil contaminated status in GC32 pipe line dry oil lake and wet oil lake, Burgan oil field, state of Kuwait by using GIS application and field investigation including soil sampling, logging in order to determine the magnitude of damage, mapping present day contamination boundaries, extent of contamination and volume of contaminated soil in the area of study. In fact, the study clearly indicates that the problems persist even after 25 years although the lakes and lagoons
\end{abstract}


that contained oil have been drained and many of them have dried out, their hazard potential has actually increased.

\section{Keywords}

GIS, Mapping, Oil Contamination, Dry Oil Lake, Wet Oil Lake

\section{Introduction}

The State of Kuwait is located at the northwestern corner of the Arabian Gulf and occupies an area of $17,830 \mathrm{~km}^{2}$. Refer to Figure 1: location map of the study area covering Burgan and Greater Burgan oil fields, State of Kuwait [1]. The oil fields in the country are found in two main parts; the northern part which comprises the Ratqa, Raudatain, Sabriya and Bahra oil fields (143 oil wells), and the southern part which includes the Greater Burgan, Managish, Umm Qudair and Wafra oil fields (766 oil wells). The Greater Burgan consists of three distinct oil fields; namely, Al Ahmadi, Burgan and Magwa. Refer to Figure 2: Location of Burgan oil field in State of Kuwait [2].

Kuwait has undergone serious environmental damage due to the formation of "oil lakes" and hydrocarbon surfaces created in the desert following the 1991 Gulf War. There were 810 active wells in Kuwait out of which 730 were damaged or set ablaze during the Gulf War [3]. The free flowing crude oil spilled over the desert surface accumulated to form "oil lakes". These are unique and can be considered to be one of the worst environmental disasters of recent times. Oil contamination caused serious damage to the environment. Figure 3 shows fires in well head inside Burgan oil field. As a result of the presence weathered crude oil; soil physical, chemical and geochemical properties were negatively affected. The persistence of extremely highly weathered oil and TPH levels suggests

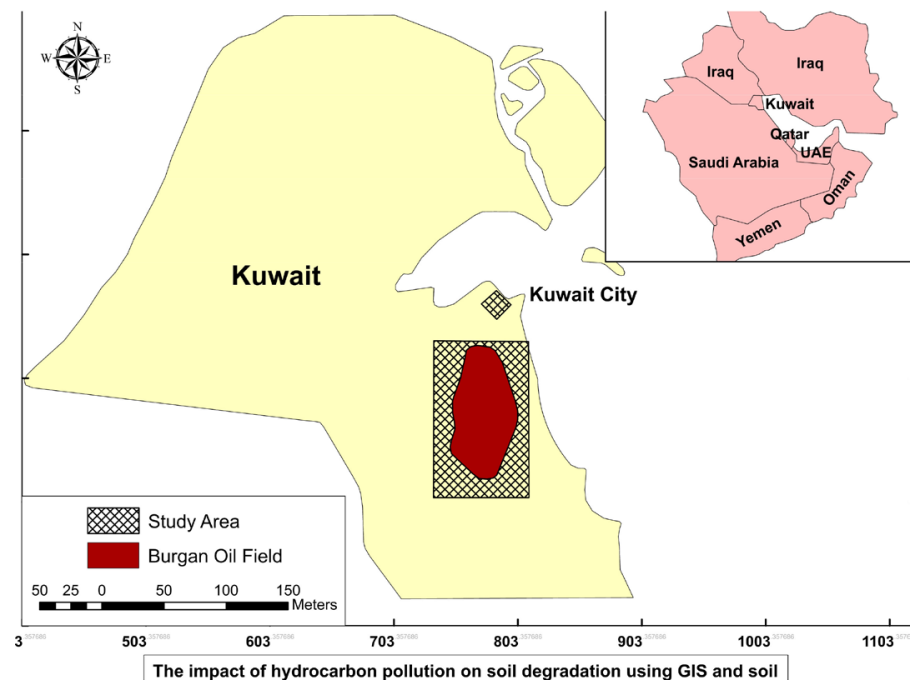

Figure 1. Location map of the study area covering Burgan and Greater Burgan oil fields, State of Kuwait [2]. 


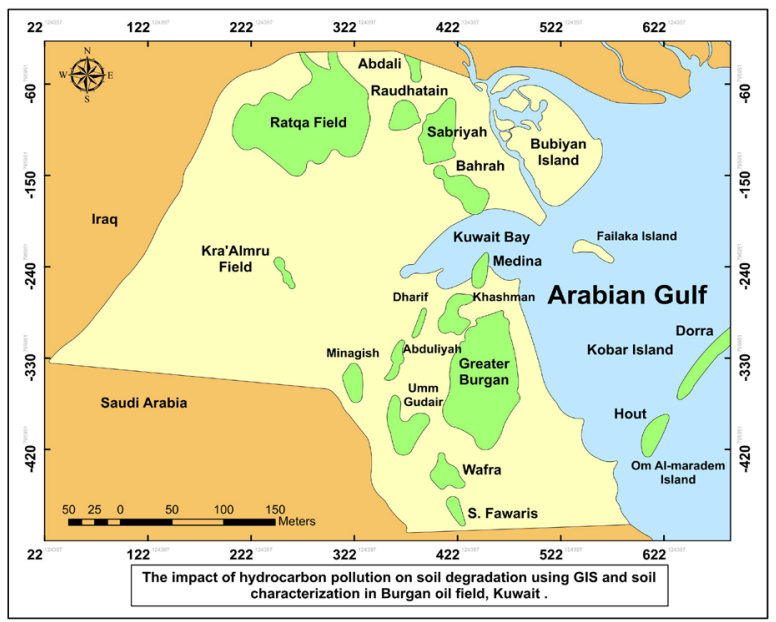

Figure 2. Location of Burgan oil field in State of Kuwait [2].

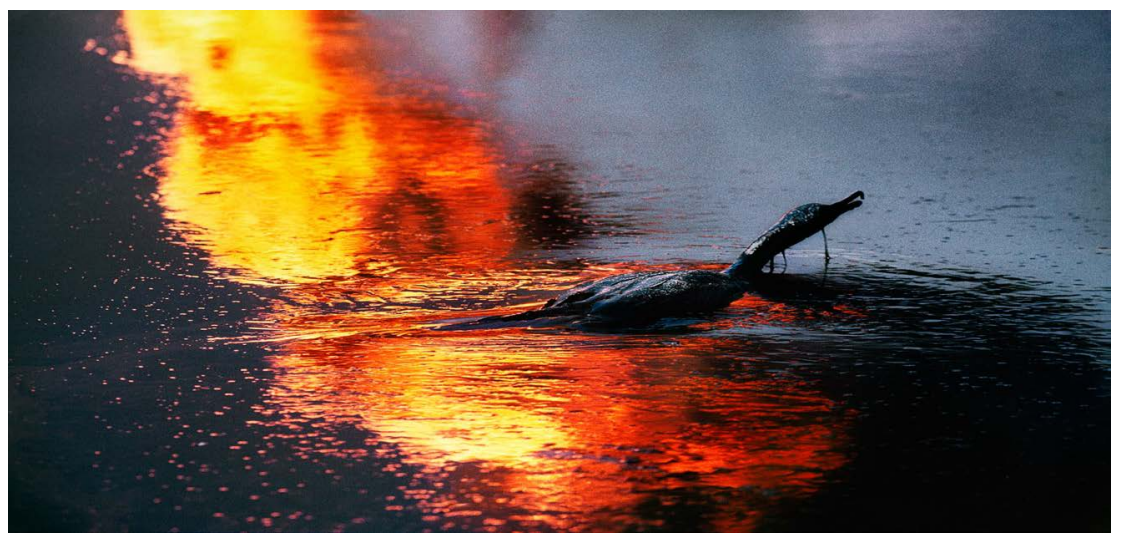

Figure 3. Fires in well head inside Burgan oil field, a picture of a dead bird in one of the oil lakes [5].

that the oil contaminated soils would require to be remediated in order to reduce the adverse environmental impacts to Kuwait's desert. Therefore, a remediation demonstration strategy is developed to assess and field test various remediation technologies in restoring the oil contaminated soil areas [4]. Geographic Information Systems (GIS) provide a powerful tool in managing and analyzing spatial data. Geographic Information System has been applied successfully to large variety of fields, one field of particular interest is the field of disaster identification and mitigation represent in the impact of hydrocarbon pollution on soil degradation in Burgan oil field, South Kuwait. It is well understood that hazard identification and land management play a major part in reducing the impact of natural disasters. This is a role GIS is well suited to especially when combined with field investigation work. GIS and databases are widely used in natural resources management and environmental science. The present study was conducted to estimate the extent and volume of contaminated soil by using GIS application and field survey. The long term impact of oil pollution on the environment of Kuwait (study area) has been assessed in this study to determine the 
extent and volume of damage by GIS application and site investigation through soil site characterization. Oil contamination in the terrestrial environment of Kuwait occurred from the detonation of preexisting oil wells in study area, Burgan, Kuwait. The following damages have been taken place as results from the invasion: 1) Oil spreading over the land surface and penetrating the soil to varying depth, 0.30 to $1.5 \mathrm{~m}$ depth, 2) Aerial fallout from oil spray and combustion products from oil fires, and 3) Formation of oil lakes (dry oil lake and wet oil lake) on the land surface. Figure 3 shows fires in well head inside Burgan oil field and formation oil lake.

The spilled oil was collected in several locations around the damaged oil wells such as natural desert depressions, deflated erosional surfaces and dry drainage networks which later formed what is known as "oil lakes". As the Greater Burgan, Raudatain and Sabriya oil fields sustained most of the damage, the majority of oil lakes were formed in these areas. Approximately 300 lakes were formed, which varied greatly in area, shape, size, depth and type of oil. The total volume of soil contaminated reached $22,652,500 \mathrm{~m}^{3}$ [6].

GIS has been the main tool used for estimating the area and extent of contamination and to monitor changes with time. To estimate total volume of contaminated soil requires knowing both the area and average contamination depth of each lake. Whilst previous studies have characterized and quantified the contamination for specific sites [7] [8] [9], they have not estimated area and depth with sufficient accuracy and in any case too few sites have been studied to allow accurate volume estimation for the entire oil field, therefore this field survey study was designed to provide the geo-referenced, ground-truth information on the volume and extent of contaminated soils in the GC32PL, Greater Al-Burgan oil field at a more intensive scale than previous studies. The estimated area of oil lakes in the Greater Al-Burgan field range from $14.07 \mathrm{~km}^{2}$ [10] to $35.45 \mathrm{~km}^{2}$ [11] and $24.14 \mathrm{~km}^{2}$ [12]. The large variation in results is due to the different techniques employed, each with different accuracies, and also to the inherent dynamics of the oil lakes as they dry, seep away, and are covered by a sand veneer. Furthermore, the accuracies of these estimates, both of area and volume are unknown because there has been limited groundtruthing data. To estimate the total volume of contaminated soil requires knowing both the area and average contamination depth of each lake. The present work is an integrated part of a series of studies carried out on soil profiles affected by oil lakes in the Greater Burgan area in order to determine the level of contamination and depth of oil penetration within the profiles and it throws light on the physical properties of these soils, which may influence the downward migration of oil pollutants.

Similarly of what happened in Kuwait desert from oil spill resulted in Iraq invasion, it had been happened in other countries from the oil spill. For examples in Mexican Gulf the BP oil spill flowed for three months, becoming the largest accidental marine oil spill in the history of the petroleum industry. The spill stemmed from a sea-floor oil gusher that resulted from the April 20, 2010, explosion of Deepwater Horizon, which drilled on the BP-operated Macondo 
Prospect. The explosion killed 11 men working on the platform and injured 17 others. Also in Fergana Valley, 1992 Uzbekistan Nearly 88 million gallons of oil spilled from an oil well in Fergana Valley, one of Uzbekistan's most active energy- and oil-refining areas. While the spill didn't get much press at the time, it is the largest inland spill ever reported. The ground absorbed this spill, leaving nothing for cleaning crews to tackle [13] therefore, the problem of oil spill is persisting all over the world and it should be assessed properly in order to tackle it and assess the environmental impact assessment using the new techniques to treat the problem from its roots.

\section{Aim of Study}

This study aims to highlight the high level achievements of the environmental assessment for the oil contaminated status in Gathering center 32 (GC32 PL.) Burgan oil field, state of Kuwait by using GIS application and field investigation. These information will be used to aid subsequent rehabilitation planning and monitoring, and to provide a basis for future detailed quantification surveys. Therefore the objectives of this survey were to: 1) categorize the types of oil contamination damage, 2) map the extent of damage, and 3) estimate the volume of contaminated soil. Reconnaissance field studies have typically assessed the contamination depth, total petroleum hydrocarbon concentrations and oil contamination area.

\section{Geology of Greater Burgan, Kuwait.}

Geomorphologically the Kuwait land surface is flat and slopes gradually north-eastward with an Average gradient of about $2 \mathrm{~m} / \mathrm{km}$. Kuwait's desert can be divided into four physiographic provinces: Al-Dibdibba gravelly plain; southern desert flat; coastal flat; and coastal hills [14]. The surface of Kuwait is carved into a clastic deposit sequence, which is locally called the Kuwait Group, and ranges in age from Miocene to recent [14] [15]. The Kuwaiti desert as described [14] is covered by several types of recent surface sediments. These are: Aeolian deposits; residual deposits; playa deposits; desert plain deposits; slope deposits; and coastal deposits. Aeolian sand deposits are the most frequent and cover many parts of Kuwait. Gypcrete is very abundant in the north where it has developed from gypsum Precipitation in the upper horizon of the sand gravel deposits of the Al-Dibdibba formation. Calcrete and silcrete are more dominant in the south where they cap several isolated hills, e.g. Wafrah, Burgan and several hills in the Al-Wafra area. The stratigraphic column of Kuwait as stated [14] is dominated by the stable shelf conditions of the Arabian crustal plate since the Paleozoic (245 to 570 million years) and the early Mesozoic Periods (less than 245 million years old), causing the deposition of a thick sequence of shallow water sediments and evaporites. Within Early Miocene time (less than 24 million years old) a peripheral basin formed at the northwest side of the Zagros belt, covering the northwest part of the Arabian Gulf and the Arabian Peninsula. 
Continental clastics shed from the east and west highlands filled the shallow basin, forming the upper Tertiary sequence of Miocene to Pleistocene age. The Kuwait Group, which ranges in age from Miocene to Pleistocene (less than 24 million years old), represents a sequence of clastic sediments 150 meters in thickness. It may be divided into three formations. These are, from top to bottom: Dibdibah, Lower Fars and Ghar Formations, which were described earlier. The degree of cementation varies with depth, most are cemented with evaporites and carbonates. The environment of deposition is continental and evaporitic with shallow marine components. Lenses of fresh water were found within the Kuwait Group, such as Al Raudhatain and Umm Al-Aish fields. The Hasa Group from top to bottom consists of: Dammam, Rus and Umm Radhuma, ranging in age from Middle Eocene to Paleocene (47 - 67 million years). An erosional unconformity separates the Kuwait Group from the Hasa Group, this unconformity is represented in the basal clay or cherty layers of varying thickness. The Hasa Group has a wide extent from Saudi Arabia through Kuwait and Iraq to Iran. The Dammam Formation underlies the whole of Kuwait and averages 250 meters in thickness. It consists mainly of shaly and chalky limestone with cherts, anhydrites and dolomites. During the Middle Eocene epoch (about 18 million years) an invasion of fresher water brought about the widespread deposition of carbonates. The depositional environment was probably shallow marine grading into continental conditions. Brackish water in large quantities was found within the Dammam Formation, which is highly karstified at several depths in the southwest corner of Kuwait. The oldest exposed outcrop in Kuwait is of the Dammam limestone, which is Middle Eocene in age (about 47 million years), and is uncomfortably overlain by the terrigenous sequence of Kuwait Group deposits. It outcrops in a small area in the southern part of Kuwait which may be related to the regional structure of Kuwait. The most common surface deposits associated with the Dammam Formation and Kuwait Group in general is the "Gatch Layer". This is sand highly cemented with salt, i.e., calcrete cemented with calcite and gypcrete cemented with gypsum. The oil reservoirs are concentrated in the Aruma, Wasia and Thamama Groups of the Cretaceous System (67 - 144 million years), which varies in thickness from about 2070 meters in southeast Kuwait to about 3450 meters in north -west Kuwait. The lithology is predominantly limestone and subordinate shale, with two major oil-bearing sandstone formations in the Lower and Middle Cretaceous. These are the Zubair Formation, which is approximately 450 meters thick, and the Burgan Formation, which is approximately 380 meters thick. Other oil producing formations are the Ahmadi, Wara, Mauddud, Zubair, Ratawi and Manaqish. Quaternary and Tertiary gravels of igneous and metamorphic origin cover most of Kuwait's desert surface. These were deposited during a fluvial stage of the Pleistocene. Pleistocene and Holocene carbonates and evaporites are widely distributed along the Kuwait coast. Figure 4, Geological map for State of Kuwait illustrates the different formation. 


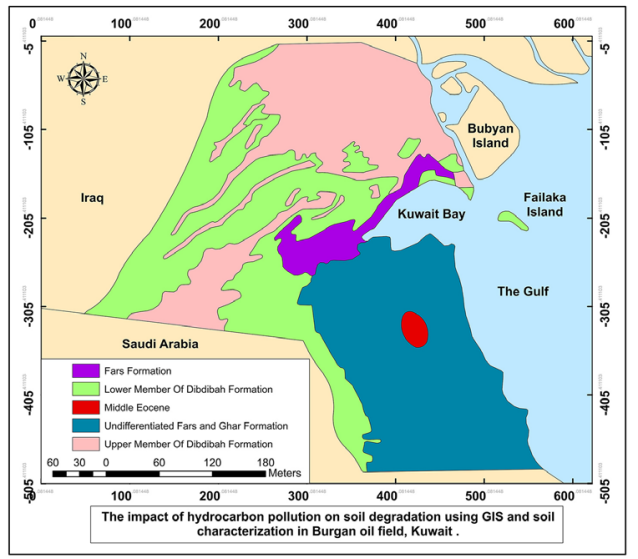

Figure 4. Geological map of Kuwait [14].

\section{Metrology and Site Description}

Kuwait is situated in the north western corner of the Arabian Peninsula between latitudes $28^{\circ} 30^{\prime} \mathrm{N}$ and $30^{\circ} 05^{\prime} \mathrm{N}$ and longitudes $46^{\circ} 33^{\prime} \mathrm{E}$ and $48^{\circ} 35^{\prime} \mathrm{E}$. The climate of Kuwait is characterized by extremely high temperatures during summer, short mild winters, high sunshine hours, low humidity and generally dry condition. The mean rainfall is $118 \mathrm{~mm} /$ year, mean temperature is $37.4^{\circ} \mathrm{C}$ and maximum mean temperature is $45^{\circ} \mathrm{C}$. The investigated area in this study lies in gathering center 32 pipeline (GC32PL) which located in the greater Al-Burgan oil field, the south of Kuwait. The study area covers about $800,000 \mathrm{~m}^{2}$ of the Burgan oil field, area is large in extent and the distribution of damage is complex, requiring that a sound methodology be established. There is a wide range of contaminated conditions in the area and it was categorized into two different zones based on the contamination feature type from dry oil (zone 12) to wet oil lakes (zone 13) to relatively "clean" soil by visual observation, and the contamination was varied markedly over short distances both spatially and with depth, [7].

\section{Methodology}

To assess the magnitude of contamination damage in the study area, information on the extent and type of damage is required. Two tracks were applied in this study 1; Groundtruthing through satellite imagery and GIS analysis. 2; field survey through site soil characterization, and to carry on that successfully the sampling sites should selected properly to assess where oil contamination exists and to provide supporting quantitative and qualitative data to assist with mapping and characterization of the oil contamination. GIS has been the primary tool used for estimating the area, extent of contamination, and changes over time [2] [11] [16], and the present status through survey study investigation. Other methods of investigation were used during this study include using laser-induced fluorescence to examine soil color, soil texture, soil consistency, and GPS was used in the methodology to accurately determine the three-dimensional test points easting, northing and the height in reference to Mina Al Ahmadi 
construction datum (MACD).

An approach based on soil survey concepts using GIS was adopted because this methodology is proven for mapping and providing information over a large area using a sparse site density and limited analytical data set [17]. This approach can efficiently draw on existing data sets of varying quality and combine them with the sampling data set to improve the quality of the output and to reinforce confidence in the final result. This study multifaceted approach used several sources of information, field survey observation data, satellite imagery (2002 \& 2016), existing mapped information, soil profile and logging the existing visual contamination in addition to total petroleum hydrocarbon (TPH) analysis for the collected samples. At field survey through site soil characterization, Key variables measured were contamination depth (by measuring at field during sampling activities), total petroleum hydrocarbon concentrations (TPH) (USEPA 9071 method 2016), a measure of oil contamination by using field tools, logging, soil color (Munsell color chart), soil texture soil consistency, landscape description and to identify sampling points location accurately hand held GPS has been used.

The spatio-temporal variation in the thermodynamic properties of surface material has been mapped in order to identify initially hydrocarbon polluted surfaces boundaries using satellite imagery data (2002 \& 2016) earth's surface material to make comparison between previous oil contamination boundaries and present day boundaries after the field verification through groundtruthing, and soil sampling. The field work procedures consist of two major activities first process is the groundtruthing (GIS) (Initial study of satellite images (2002 \& 2016) and second process is the site investigation including soil profiling and sampling. The purpose of the groundtruthing study was to present the reviewed results of historical and recent satellite images and results of pre-condition survey for the study area (GC32 PL) inside Kuwait Oil Company fence(KOC), a part of 3B subarea (KOC sub divisions for the contaminated areas inside Burgan Oil field), also it includes the assessment of present contamination and under/above ground utility services that were identified during site survey, the findings of groundtruthing was used for delineating the present boundary of the contamination based on which the present area of soil contamination is estimated. Site soil characterization process was carried out through locating sampling points and collects soil samples for TPH laboratory analysis, profile the vertical contamination and to modeling the extent of the soil contaminated layers. All These data together defined the volumes and quantities of heavily contaminated soils, total petroleum hydrocarbon, and the oil contamination extension within the area of study. All data was entered into a database for analysis and map information was manipulated by a geographical information system, the map shows polygons and each polygon identifies the class of contamination within it essentially, the map unit boundaries indicated where it is expected that there will be a marked change in the type of oil contamination whether it is dry 
oil lake or wet oil lake, its level of concentration and depth of contamination, and this indicated that the map units correctly cover all the classified contaminated features within study area. The area for each individual polygon was calculated using GIS and then those in the same map unit category were summed together. The contaminated soil volume was calculated from the area measurements with multiplication by the mean contamination layer thickness that occurred for that map unit category and with the assistance of surfer software. So the Application of GIS and surfer software was essential to calculate the volume of contamination in this study.

\section{Results and Discussion}

Massive pollution of marine and terrestrial environments resulted from the destruction of Kuwait's oil production facilities at the conclusion of the Iraqi occupation. There are four types of oil contaminated soils (features) mainly: Dry oil lake contamination (DOL); Oil-contaminated piles (OCP); Wet oil lake contamination (WOL); and Wellhead Pits (WHP) two features types were identified within this study dry oil lake and wet oil lake. The short- and long-term consequences of this disaster to the terrestrial environment can be grouped into six categories: 1) soil compaction due to increased movement heavy military vehicles throughout the desert; 2) surface sediment disruption due to the placement of mines, construction of bunkers, foxholes and other physical infrastructure related to war activities; 3) degradation of vegetation and wildlife habitat; 4) soil contamination with petroleum hydrocarbons and heavy metals; 5) ground water pollution; and 6) impact on marine environment and coastal ecosystems. There was also significant negative impact on public health as well. The study was carried out on the Oil Lakes inside GC32 PL, Burgan oil field these lakes are classified into two major categories or features based on the texture and compositions of contaminant. First category is the wet oil lake, areas covered by black liquid or semi-solid oil material, over oil-contaminated soil, resulting from the surface flow of oil from damaged oil wells. It occurs in areas where liquid oil accumulated because of micro-relief and local topography. The consistency of wet oil lakes can change from solid during winter months to soft during hot summer months, creating temperature induced viscosity changes, refer to Figure 5 photos showing the texture of wet oil lake during site investigation. Such places include shallow depressions and drainage channels, the liquid oil surfaces may have a thin, hardened layer on the surface although it is not strong enough to support the weight of a person. Sludge material has been found to contain mean TPH concentrations in excess of $19 \%$, underlying contaminated soil was found to contain a mean average $3.4 \%$ for TPH concentrations, the deeper layer had mean average TPH concentrations in the range of $0.06 \%$. Figure 8 shows general view for the wet oil lake during site investigation.

Second category is the Dry oil lake, Dry oil lakes are areas covered by a thin black, moderately hard, tar-like dry surface layer, at times with a layer of oil 


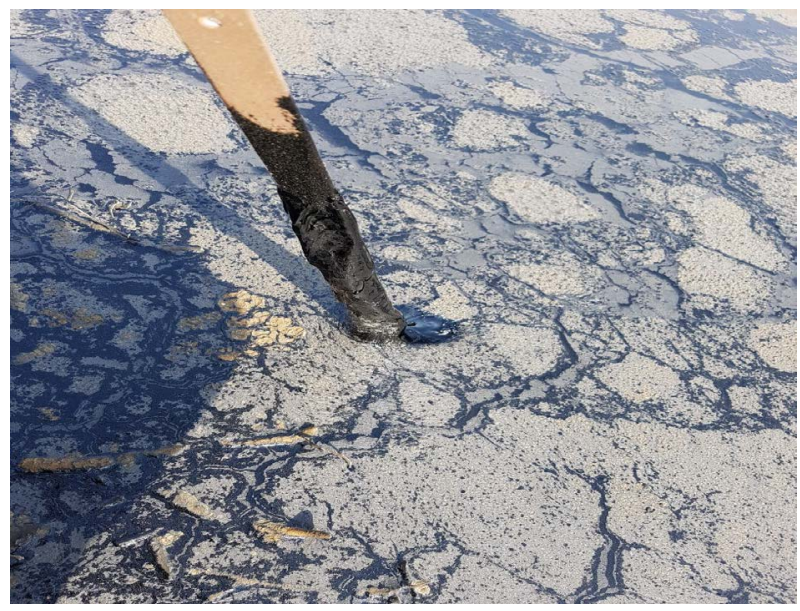

(a)

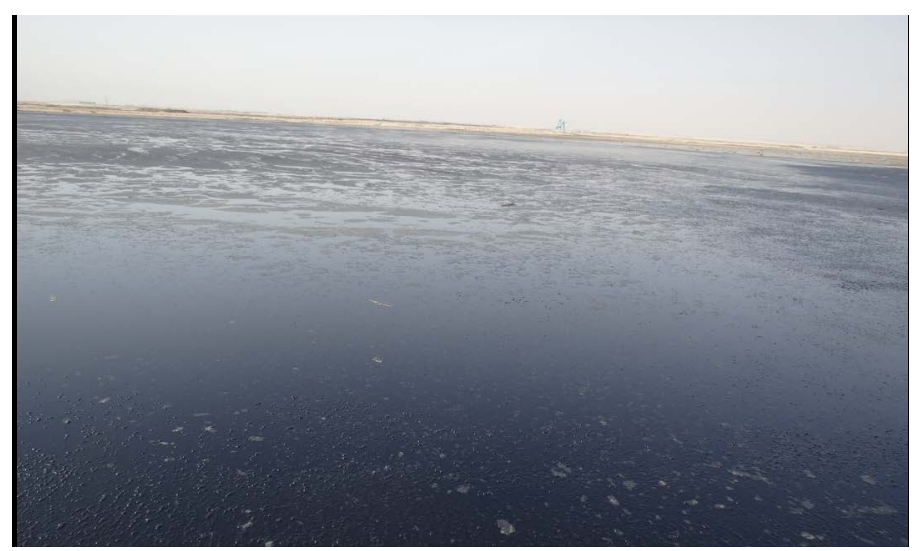

(b)

Figure 5. (a) Investigation of the crude depth within wood stick study area; (b) Crude and oil sludge layer covering top of the lake within study area.

sludge overlying dark brown oil-contaminated soil that in turn overlies soil with no visible oil contamination. These were created by the flow of oil over the surface from damaged oil wells. The dry oil lakes are generally found in shallow depressions and flat areas, often forming fringe areas around wet oil lakes, the surface tar material in areas of dry oil contamination was found to contain mean TPH concentrations of approximately $7.3 \%$ underlying contaminated soil was found to contain mean $2.5 \%$ TPH concentrations, the deeper layer had mean TPH concentrations in the range of $0.07 \%$. Site soil characterization (site investigation) of the dry oil lakes contamination has been undertaken in this study to profile the following vertical depths of heavily oil contamination $(0-20 \mathrm{~cm})$, residual oil contamination zone $(20-40 \mathrm{~cm})$ and clean zone $(40-80 \mathrm{~cm}$ or greater) at 5 grab sampling points and determine the total TPH levels (USEPA method $9071 \mathrm{~B}$ or equivalent) of composite sample for each depth of the 5 grab sampling points. There is changes in the transition from dry oil lake to wet oil lake contamination are expected to have taken place between 2002 and the current study time 2017 (Figure 8) related to the natural degradation processes caused by exposure to air, heat, water, and wind-blown sand, natural degrada- 
tion processes have not been expected to significantly decrease the land surface areas covered by oil contamination. Continued seeping of oil into the soil under the wet oil lakes and wind-blown sand sinking into the edges of wet oil lakes are expected to result in the transition of dry oil lakes features to wet oil lakes, the degree to which this transition is occurring has been quantified within the present study, refer to Figure 7 and Figure 8 for the variance between present day contamination boundaries (2016) compared to the same contaminated boundaries in 2002 within the study area. Refer to Figure 9 for resulted GIS map summarize the changes estimation in areas between Dry oil lake and Wet oil lake within the study are in 2016. In this study to profile the following vertical depths of heavily oil contamination and delineate the present day boundaries, about 60 sample location within test pit have been carried out on two different zones (zone12 and zone 13) in the study area as depicted on following map (Figure 6).

\section{Site Soil Characterization Process}

Site Soil characterization is divided into 2 main processes: Field investigation and volume calculation.

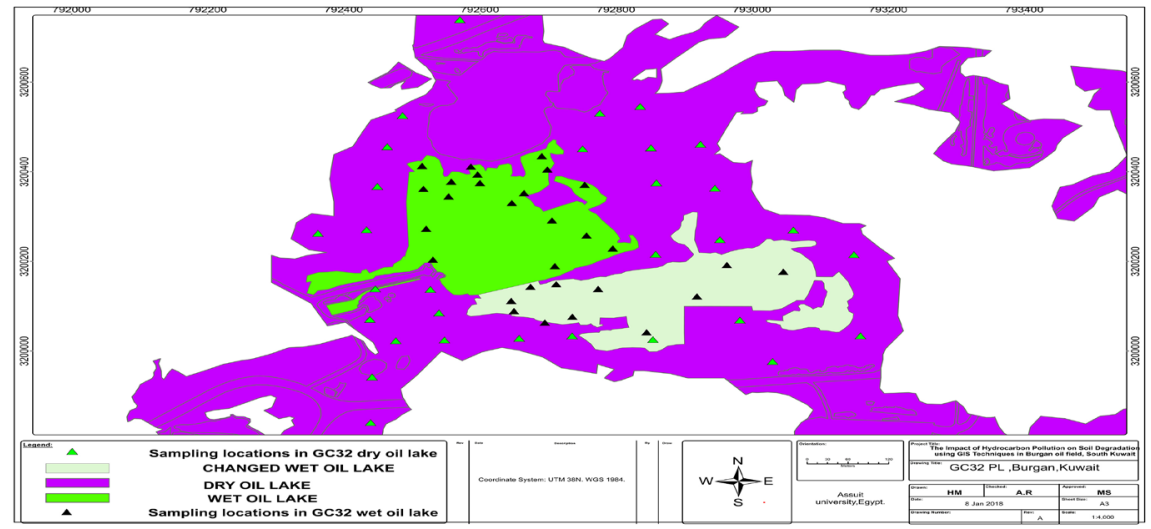

Figure 6. Locations of test pit and Sampling Location inside GC-32 PL.
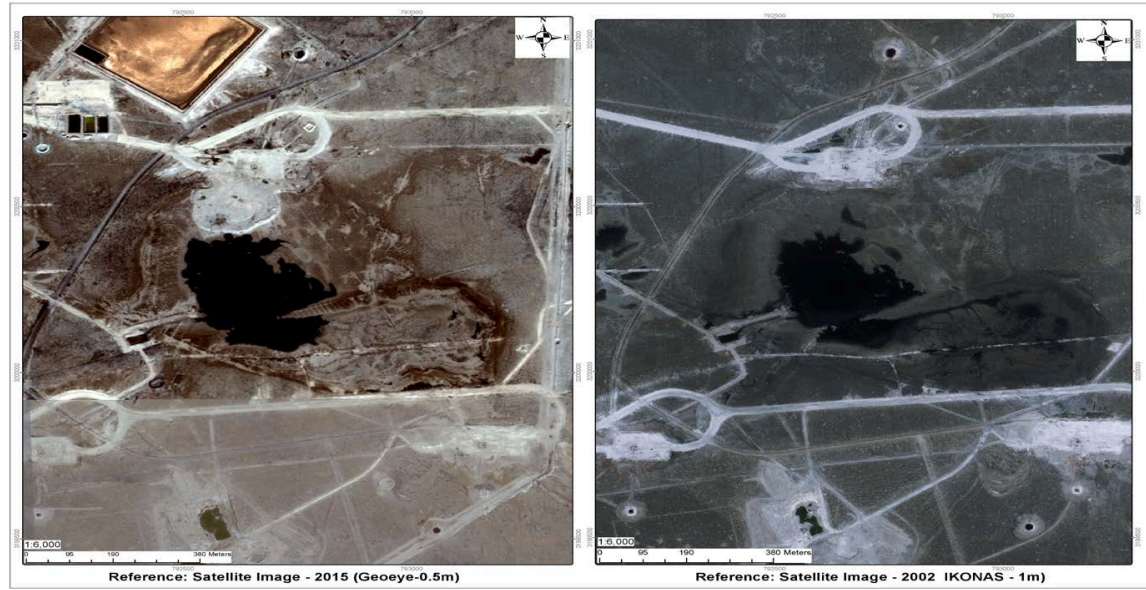

Figure 7. Satellite image showing contamination status comparison between 2002 \& 2016 before field verification. 

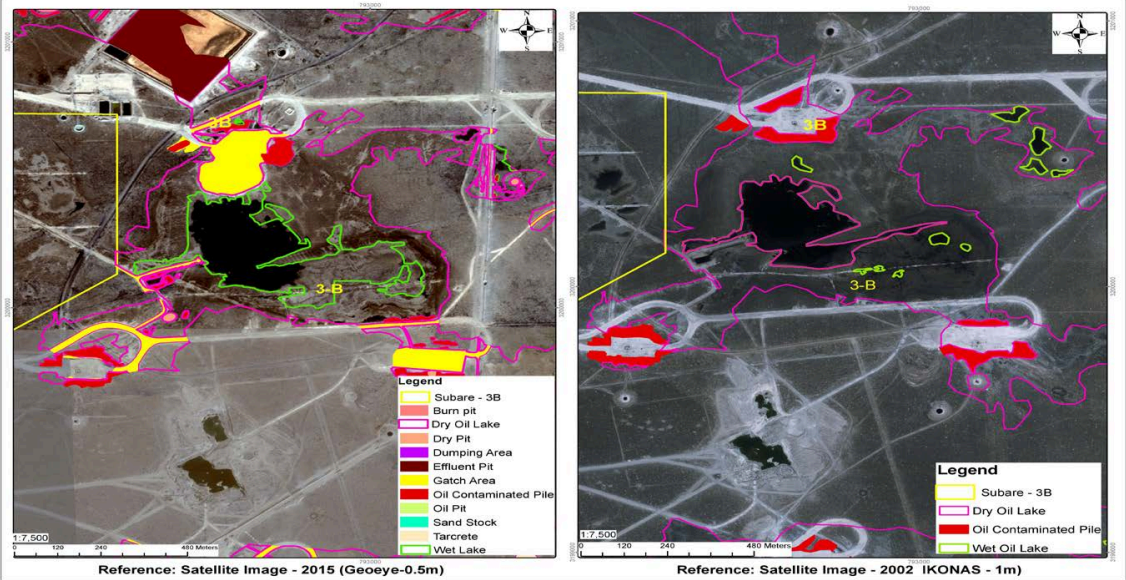

Figure 8. Satellite image showing delineated boundaries of oil contamination upon field verification in GC32 pipe line area, Burgan (2002 \& 2016).

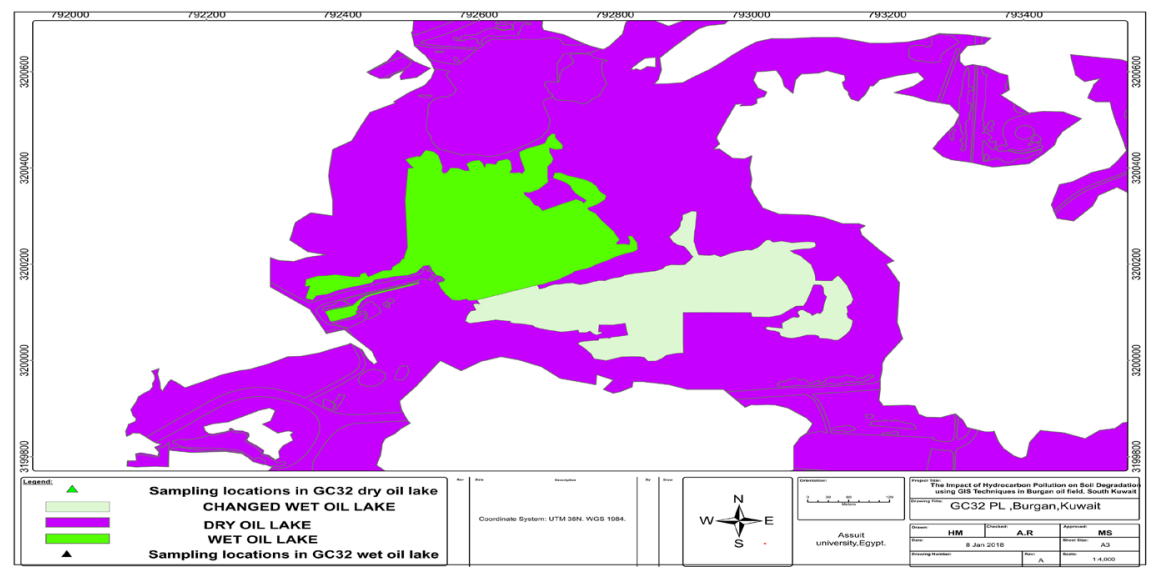

Figure 9. GIS map showing the boundaries between the different wet and dry features in study area. Area of wet oil lake contamination changed from $75,483 \mathrm{~m}^{2}$ (2002) to $145285.43 \mathrm{~m}^{2}$ (2016).

\section{1) Field investigation}

The field investigation is comprised of soil sampling of the contaminated layers following an approved methodology, profiling contamination thickness and characteristics of soil using BS5930 standards this study presents description and results of site soil characterization activities carried within area GC32 PL in both dry oil lake and wet oil lake feature particularly inside Kuwait Oil Company fence, burgan oil field to delineate the present day boundaries between wet and dry oil lake contamination and between the external boundary of contaminated area with the clean environment, refer to Figure 10 and Figure 11 photos showing examples for the field team site activities during the investigation. Contaminated features divided into two zones (zone 12 for dry oil lake and zone 13 wet oil lake) based on grids distribution and homogeneity of sampling pits as shown in Figure 12 and Figure 13. The objective of this site characterization within this study is to determine the level of contamination in the above-mentioned 


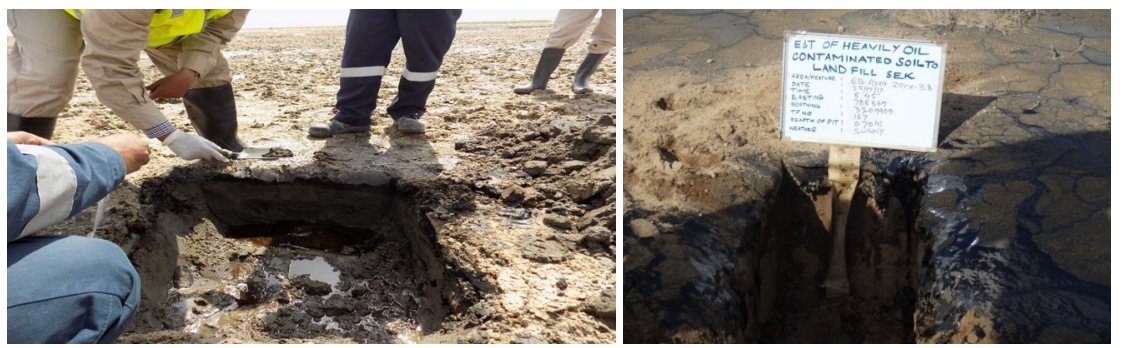

Figure 10. Field team was carrying out site investigation and logging inside sampling trial pit.

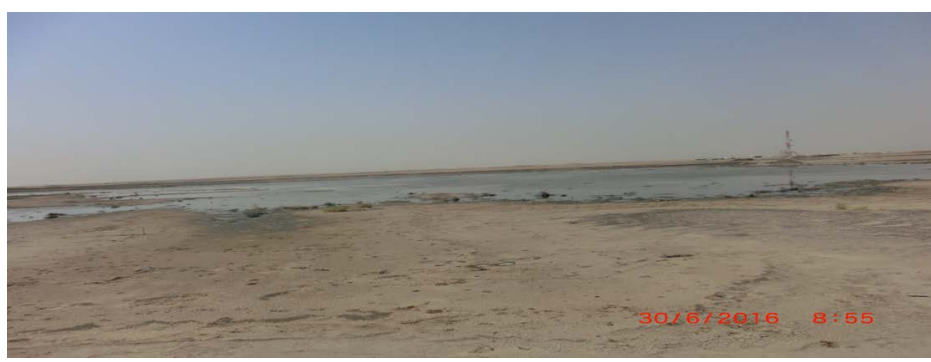

Figure 11. Boundaries between Dry oil lake and Wet oil lake in the study area.

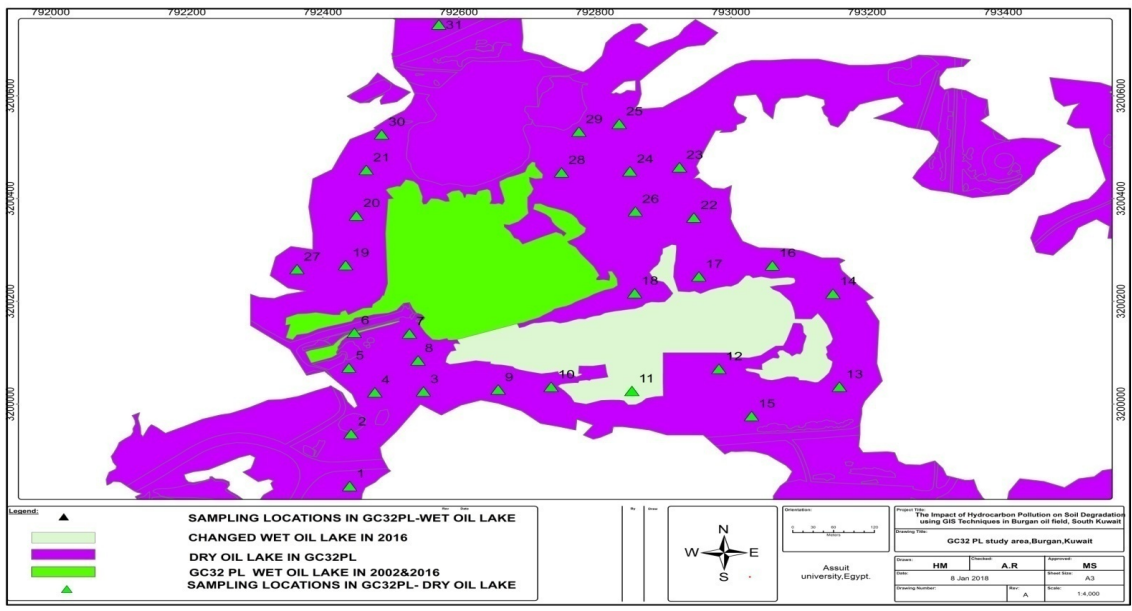

Figure 12. Site soil sampling Locations inside GC-32 dry oil lake zone 12.

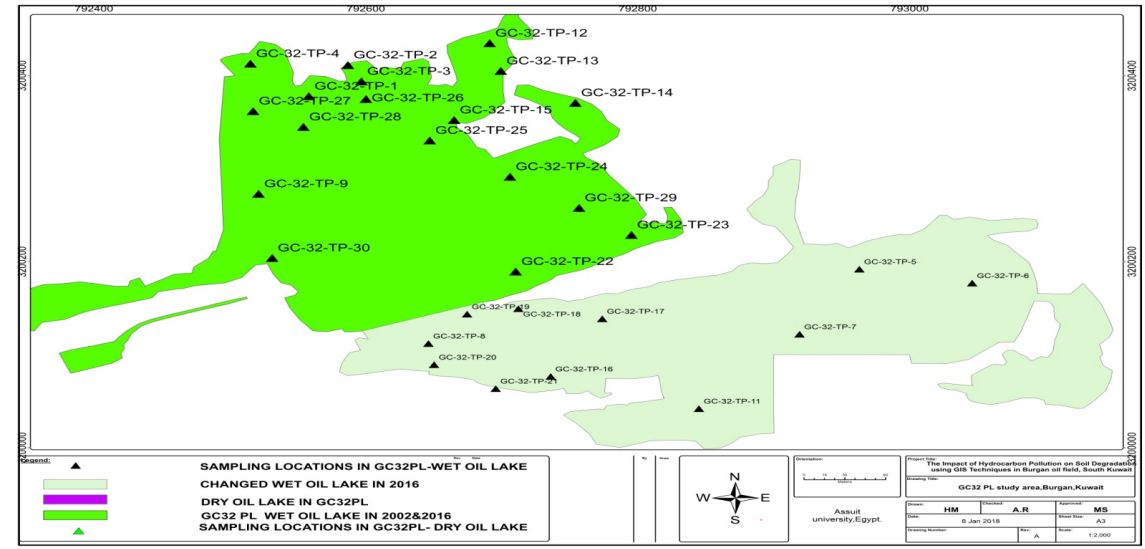

Figure 13. Site soil sampling Locations inside GC-32 pipeline area wet lake zone 13. 
zones and to estimate the volume of contaminated soil (surface crude oil and subsurface soil contamination). The analysis of the field data is used for volume calculations and for the estimation of the depth to base of contaminant. The level of contamination is represented as the Total petroleum hydrocarbon test (TPH) which is an indicator for the presence and amount of oil contaminants in a soil matrix, and it was determined in both wet oil lake and dry oil lake in GC32PL, as for the GC32 PL dry oil lake zone 12, TPH were analyzed using US EPA method $9071 \mathrm{~B}$, the analysis was carried out on dry basis,. All Composites made from layer 1 the average TPH value was $67,301 \mathrm{mg} / \mathrm{kg}$ indicating highly contaminated soil. All Composites made from layer 2 the average TPH value was $13,738 \mathrm{mg} / \mathrm{kg}$. All Composites made from layer 3 the average TPH value was 535 $\mathrm{mg} / \mathrm{kg}$ indicating clean soil within the clean up criteria. As for GC32 wet oil lake zone $13 \mathrm{TPH}$ the analysis was carried out on dry basis. TPH Values were reported to be greater than $305,816 \mathrm{mg} / \mathrm{Kg}$ of Layer 1 sample; TPH value is 73,941 $\mathrm{mg} / \mathrm{Kg}$ of layer 2 samples and TPH Value $1508 \mathrm{mg} / \mathrm{Kg}$ of layer 3 sample. Average TPH value is $480,068 \mathrm{mg} / \mathrm{kg}$ of layer 1 of all 18 composites. Average TPH value is $136,521 \mathrm{mg} / \mathrm{kg}$ of layer 2 of all 18 composites. Average TPH value is $2805 \mathrm{mg} / \mathrm{kg}$ of layer 3 of all 18 composites. Therefore, TPH results shows that all composites of layer 1 of trail pits 1 - 5 are highly contaminated. Layer 3 is faintly contaminated. Therefore, contamination level is decreased by going down to depth.

After the analysis of visual data, collected samples and using GIS application in GC32 pipe line, it is inferred that the total volume of oil contamination about $168776.55 \mathrm{~m}^{3}$ of dry soil contaminant was calculated within zone 12 in GC32PL-DL area and an estimated total area of contaminated soil of $=557617.136 \mathrm{~m}^{2}$, and the investigation was carried out by using 30 sampling trial pits spread all over the area in zone 12 .

As for wet oil lake in GC32PL, the depth of contamination for layer 1 which consisting of crude oil ranged from 0.08 to $0.90 \mathrm{~m}$ and the depth of contamination for layer 2 subsurface contaminated soil ranged from $0.15 \mathrm{~m}$ to $0.9 \mathrm{~m}$ the investigation was carried out by using 30 sampling trial pits spread all over the area in zone 13 GC32 PL wet oil lake, Burgan oil field. A total volume of $65851 \mathrm{~m}^{3}$ heavily contaminated underlying soil layer beneath the oil sludge and a total volume of oil sludge $63,109 \mathrm{~m}^{3}$ which containing about $38,700 \mathrm{~m}^{3}$ viscous crude oil all were calculated within zone 13 in GC32PL-WOL area and an estimated total area of contaminated soil of $=145285.43 \mathrm{~m}^{2}$. Recent assessment of the current status after the groundtruthing survey within satellite imageries interpretation and field investigation through site characterization activity of the study area GC32 PL shows their extent and the distribution of the samples within the two zones in Figure 12, Figure13. The volume calculations were made on Surfer Software and area were calculated on ArcMap (GIS) all are provided in Table 1.

2) Volume Estimation 
Table 1. Extent of the WET \& DOL in area GC32 PL and the distribution of sampling points within the zones.

\begin{tabular}{cccccc}
\hline Zones & Area $\left(\mathrm{m}^{2}\right)$ & $\begin{array}{c}\text { Sampling } \\
\text { points }\end{array}$ & $\begin{array}{c}\text { Depth of } \\
\text { contamination }(\mathrm{m})\end{array}$ & $\begin{array}{c}\text { Depth of } \\
\text { sludge }(\mathrm{m})\end{array}$ & $\begin{array}{c}\text { Estimated Volumes of } \\
\text { contamination }\left(\mathrm{m}^{3}\right)\end{array}$ \\
\hline Zone 12 & 557617.1 & DOL $(1-30)$ & 0.40 to 0.60 & NA & 168776.55 \\
Zone 13 & 145285.4 & WOL $(1-30)$ & 0.08 to 1.8 & 0.08 to 0.90 & 128947 \\
Total & 702902.6 & & & & 297723.6 \\
\hline
\end{tabular}

Note, NA refers to not applicable.

Methodology of volume calculations adopted for determining the volume of contaminated soil in the subject zones is explained in this sub-section. The volumes were calculated by constructing two grid surfaces, the top and bottom of contaminant layer on Surfer and subtracting them from each other within each zone. The top layer consists of the surface topography extracted from the digital elevation model having specific dimensions. The bottom layer was generated by geo-statistically correlating bottom layer values from each sampling trial pit using the krigging method, values of bottom contaminant layer were determined such that to reach a conservative estimated volume Figures 14-16. Refer to Tables 2-4, summarize the Contamination volume and the analyzed depth of contamination in each sampling point with the coordinates (WGS 1984) in GC32 PL dry oil lake (zone 12) and GC32 wet oil lake (zone 13).Refer to Figure 17 \& Figure 18, showing contamination soil profiles during site investigation in area of study in GC32 PL dry oil lake and wet oil lake.

\section{Conclusions \& Recommendations}

Several studies have been conducted in Kuwait by local and international organizations to understand the nature and extent of the damage made by the oil lakes to the environment and ecosystem. All including results at this present study clearly indicate that the problems persist even after 25 years. In fact, although the lakes and lagoons that contained oil have been drained and many of them have dried out, their hazard potential has actually increased.

The present study was performed by testing grids at different locations within a contaminated area and a reference non-contaminated area (GC32 PL, Burgan Oil Field). Visual inspection, topography surveys through groundtruthing activities, and conventional soil investigations using soil samples collected from different depths by hand tools to profile the contaminated layers in situ and the laboratory chemical analysis were conducted on soil samples to quantify the total petroleum hydrocarbons (TPH) and extent of contamination.

The investigation of soil samples at different 60 trial test pits from different depths up to the appearance of clean soil in zone 12 and zone 13 indicated the presence of heavily contaminated soil (layer 1) up to a range depth of 0.20 to $0.90 \mathrm{~m}$, following by the presence of dark brown colored (layer 2) soil at depths from $0.50 \mathrm{~m}$ to $1.5 \mathrm{~m}$ with slight oil odor; then the soil became pale brown and 
Table 2. Contamination volume in zone 12 and zone 13.

\begin{tabular}{cccccc}
\hline 6 & Total area $\left(\mathrm{m}^{2}\right)$ & $\begin{array}{c}\text { Estimated volume } \\
\text { for excavation from } \\
\text { oil sludge }\left(\mathrm{m}^{3}\right)\end{array}$ & $\begin{array}{c}\text { Estimated volume for } \\
\text { oil sludge need to be } \\
\text { mixed }\end{array}$ & $\begin{array}{c}\text { Estimated volumes } \\
\text { for excavation be- } \\
\text { low sludge }\left(\mathrm{m}^{3}\right)\end{array}$ & $\begin{array}{c}\text { Total volume of } \\
\text { contamination in } \\
\text { GC32-PL- }\left(\mathrm{m}^{3}\right)\end{array}$ \\
\hline GC32 PL (zone 12) & 557617.136 & NA & NA & NA & 168776.55 \\
GC32 PL (zone 13) & 145285.43 & 24409 & 38700 & 65851 & 128947 \\
\hline
\end{tabular}

Table 3. Analysed depth of contamination for the zone (12) in GC32 PL-DL and their relative estimated depth of contamination $\left(\mathrm{m}^{3}\right)$.

\begin{tabular}{|c|c|c|c|}
\hline Test Pit No & Easting & Northing & $\begin{array}{c}\text { Base of } \\
\text { Contaminant }\end{array}$ \\
\hline AL-GC-32-PL-TP-1 & 792,439 & $3,199,841$ & 0.13 \\
\hline AL-GC-32-PL-TP-2 & 792,442 & $3,199,942$ & 0.17 \\
\hline AL-GC-32-PL-TP-3 & 792,548 & $3,200,025$ & 0.2 \\
\hline AL-GC-32-PL-TP-4 & 792,490 & $3,200,019$ & 0.25 \\
\hline AL-GC-32-PL-TP-5 & 792,456 & $3,200,073$ & 0.2 \\
\hline AL-GC-32-PL-TP-6 & 792,446 & $3,200,139$ & 0.2 \\
\hline AL-GC-32-PL-TP-7 & 792,527 & 3200137 & 0.15 \\
\hline AL-GC-32-PL-TP-8 & 792,540 & $3,200,085$ & 0.9 \\
\hline AL-GC-32-PL-TP-9 & 792,658 & $3,200,028$ & 0.6 \\
\hline AL-GC-32-PL-TP-10 & 792,719 & $3,199,995$ & 0.65 \\
\hline AL-GC-32-PL-TP-11 & 792,867 & $3,199,953$ & 0.55 \\
\hline AL-GC-32-PL-TP-12 & 793,032 & $3,199,975$ & 0.75 \\
\hline AL-GC-32-PL-TP-13 & 793,023 & $3,200,050$ & 0.55 \\
\hline AL-GC-32-PL-TP-14 & 792,965 & $3,200,037$ & 0.7 \\
\hline AL-GC-32-PL-TP-15 & 793,161 & $3,200,011$ & 0.6 \\
\hline AL-GC-32-PL-TP-16 & 793,146 & $3,200,218$ & 0.4 \\
\hline AL-GC-32-PL-TP-17 & 793,058 & $3,200,273$ & 0.25 \\
\hline AL-GC-32-PL-TP-18 & 792,952 & $3,200,244$ & 0.45 \\
\hline AL-GC-32-PL-TP-19 & 792,858 & $3,200,219$ & 0.55 \\
\hline AL-GC-32-PL-TP-20 & 792,795 & $3,200,196$ & 0.35 \\
\hline AL-GC-32-PL-TP-21 & 792,466 & $3,200,454$ & 0.2 \\
\hline AL-GC-32-PL-TP-22 & 792,752 & $3,200,449$ & 0.2 \\
\hline AL-GC-32-PL-TP-23 & 792,487 & $3,200,526$ & 0.2 \\
\hline AL-GC-32-PL-TP-24 & 792,484 & $3,200,300$ & 0.25 \\
\hline AL-GC-32-PL-TP-25 & 792,275 & $3,200,202$ & 0.75 \\
\hline AL-GC-32-PL-TP-26 & 792,949 & $3,200,362$ & 0.23 \\
\hline AL-GC-32-PL-TP-27 & 792,802 & $3,200,336$ & 0.25 \\
\hline AL-GC-32-PL-TP-28 & 792,923 & $3,200,502$ & 0.15 \\
\hline AL-GC-32-PL-TP-29 & 792,821 & $3,200,348$ & 0.2 \\
\hline AL-GC-32-PL-TP-30 & 792,868 & $3,200,410$ & 0.25 \\
\hline
\end{tabular}


Table 4. Analyzed depth of contamination for the zone (13) in GC32 PL-WOL and their relative estimated depth of contamination $\left(\mathrm{m}^{3}\right)$. (Alghanim international Company, Soil remediation team 2, KERP, Kuwait 2016.)

\begin{tabular}{|c|c|c|c|c|c|}
\hline Test Pit No & Zone & Easting & Northing & Layer 1 depth & $\begin{array}{c}\text { Base of } \\
\text { contaminant }\end{array}$ \\
\hline GC-32-TP-1 & Zone -13 & 792558.00 & 3200378.00 & 0.15 & 0.4 \\
\hline GC-32-TP-2 & Zone-13 & 792586.77 & 3200411.49 & 0.2 & 0.6 \\
\hline GC-32-TP-3 & Zone-13 & 792596.67 & 3200393.97 & 0.2 & 0.5 \\
\hline GC-32-TP-4 & Zone-13 & 792515.00 & 3200413.00 & 0.6 & 0.35 \\
\hline GC-32-TP-5 & Zone-13 & 792963.00 & 3200192.00 & 0.6 & 0.35 \\
\hline GC-32-TP-6 & Zone-13 & 793046.00 & 3200177.00 & 0.7 & 0.3 \\
\hline GC-32-TP-7 & Zone-13 & 792919.00 & 3200122.00 & 0.7 & 0.25 \\
\hline GC-32-TP-8 & Zone-13 & 792646.00 & 3200112.00 & 0.75 & 0.15 \\
\hline GC-32-TP-9 & Zone-13 & 792521.00 & 3200273.00 & 0.9 & 0.6 \\
\hline GC-32-TP-10 & Zone-13 & 792460.00 & 3200369.00 & 0.75 & 0.2 \\
\hline GC-32-TP-11 & Zone-13 & 792845.00 & 3200042.00 & 0.2 & 0.4 \\
\hline GC-32-TP-12 & Zone-13 & 792691.00 & 3200435.00 & 0.3 & 0.3 \\
\hline GC-32-TP-13 & Zone-13 & 792699.23 & 3200405.17 & 0.2 & 0.4 \\
\hline GC-32-TP-14 & Zone-13 & 792754.04 & 3200370.90 & 0.3 & 0.4 \\
\hline GC-32-TP-15 & Zone-13 & 792664.86 & 3200352.37 & 0.3 & 0.35 \\
\hline GC-32-TP-16 & Zone-13 & 792735.91 & 3200076.61 & 0.35 & 0.35 \\
\hline GC-32-TP-17 & Zone-13 & 792773.82 & 3200138.61 & 0.35 & 0.5 \\
\hline GC-32-TP-18 & Zone-13 & 792712.19 & 3200149.50 & 0.25 & 0.6 \\
\hline GC-32-TP-19 & Zone-13 & 792674.44 & 3200143.58 & 0.35 & 0.3 \\
\hline GC-32-TP-20 & Zone-13 & 792650.16 & 3200089.28 & 0.3 & 0.3 \\
\hline GC-32-TP-21 & Zone-13 & 792695.52 & 3200063.55 & 0.35 & 0.3 \\
\hline GC-32-TP-22 & Zone-13 & 792710.16 & 3200189.45 & 0.3 & 0.6 \\
\hline GC-32-TP-23 & Zone-13 & 792795.28 & 3200228.81 & 0.35 & 0.5 \\
\hline GC-32-TP-24 & Zone-13 & 792706.00 & 3200291.37 & 0.35 & 0.9 \\
\hline GC-32-TP-25 & Zone-13 & 792646.95 & 3200330.43 & 0.35 & 0.6 \\
\hline GC-32-TP-26 & Zone-13 & 792600.00 & 3200375.00 & 0.3 & 0.7 \\
\hline GC-32-TP-27 & Zone-13 & 792517.00 & 3200362.00 & 0.3 & 0.7 \\
\hline GC-32-TP-28 & Zone-13 & 792554.00 & 3200345.00 & 0.3 & 0.9 \\
\hline GC-32-TP-29 & Zone-13 & 792756.76 & 3200257.90 & 0.2 & 0.6 \\
\hline GC-32-TP-30 & Zone-13 & 792531.00 & 3200204.00 & 0.35 & 0.4 \\
\hline
\end{tabular}

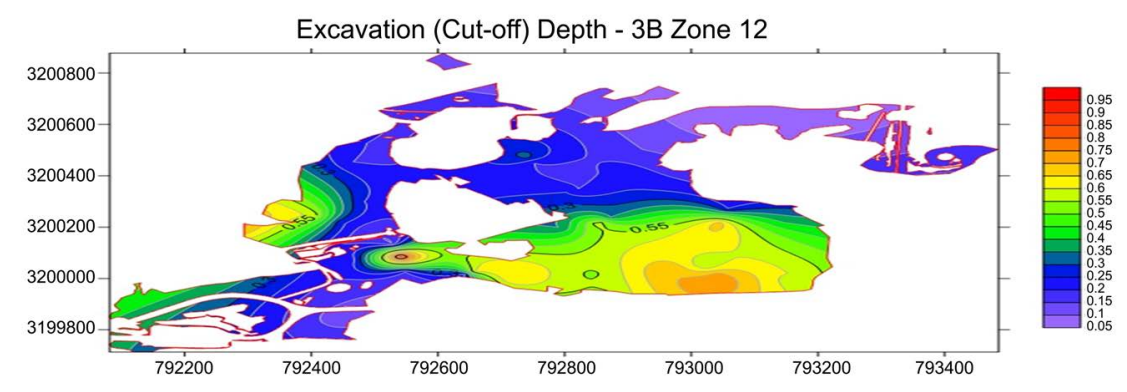

Figure 14. Contamination depth in zone 12 on surfer software. 
3B one 13 Layer 1 - Excavation Cut-off Depth

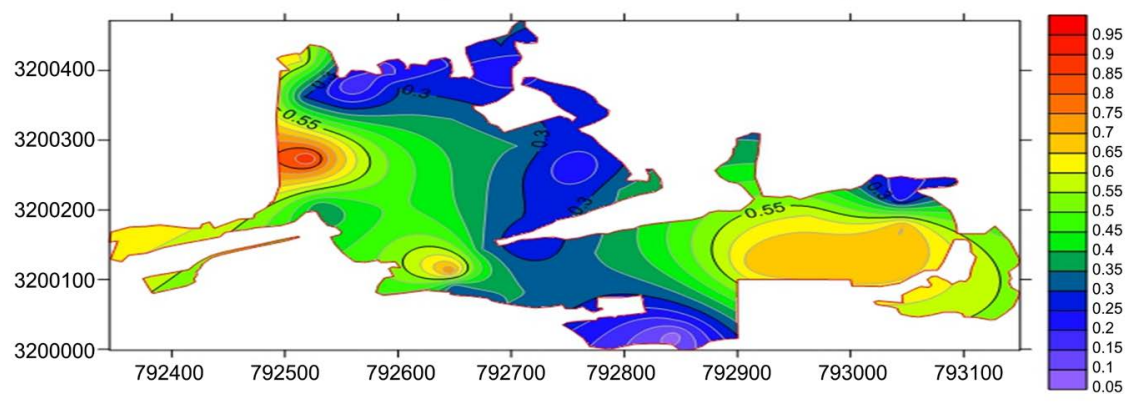

Figure 15. Contamination depth in zone 13 layer 1 on surfer software.

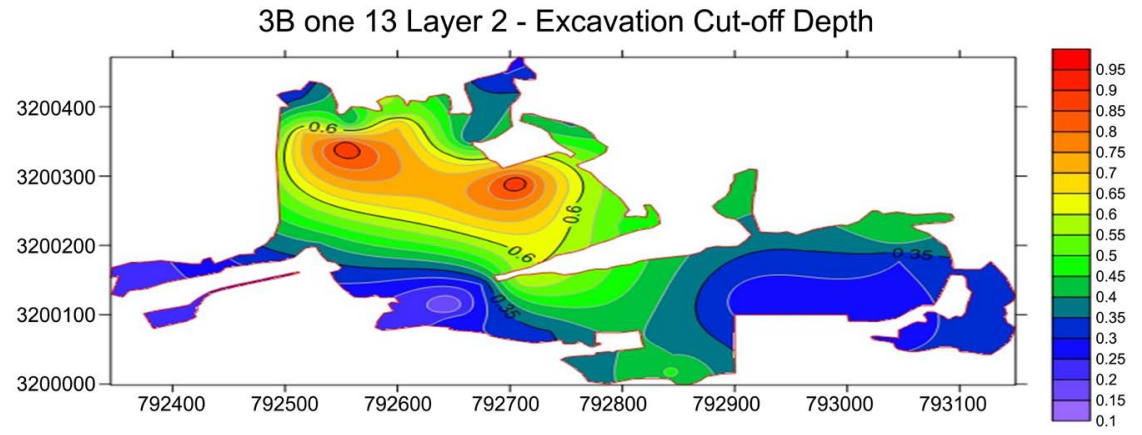

Figure 16. Contamination depth in zone 13 layer 2 on surfer software.

did not have petroleum odor clean soil represent layer 3. It is inferred that the Total petroleum hydrocarbon (TPH) for wet oil lake in the study area (zone 13), Sludge material has been found to contain mean TPH concentrations in excess of $19 \%$. Underlying contaminated soil was found to contain a mean average $3.4 \%$ for TPH concentrations, the deeper layer had mean average TPH concentrations in the range of $0.06 \%$ and as for the dry oil lake inferred that the surface tar material was found to contain mean TPH concentrations of approximately $7.3 \%$. Underlying contaminated soil was found to contain mean $2.5 \%$ TPH concentrations, the deeper layer had mean TPH concentrations in the range of $0.07 \%$, the estimated contaminated area in GC32 PL dry oil lake about $557617.136 \mathrm{~m}^{2}$, and volume of contamination calculated on surfer with an assigned level for the base of the contaminant was about $168776.55 \mathrm{~m}^{3}$. As for GC32 wet oil lake zone 13, the estimated contaminated area about $145285.43 \mathrm{~m}^{2}$, (Area of contamination has increased in 2017 by $69,800 \mathrm{~m}^{2}$ ), and volume of contamination calculated on surfer with an assigned level for the base of the contaminant was $128947 \mathrm{~m}^{3} \mathrm{di}$ vided into 63,096 of oil sludge and $65,851 \mathrm{~m}^{3}$ of wet lake below oil sludge.

It is concluded that the impact of oil contamination in the degradation of existing soil in gathering center 32 (GC32PL) about $30 \%$ and this impacted soil should be removed or remediated in situ by the adequate remediation action. Therefore, the database and GIS with the soil investigation provided essential data set for interpretation of the extent and type of contamination in the study area. It is concluded that the bulk of the contaminated soil occurs in the dry oil 


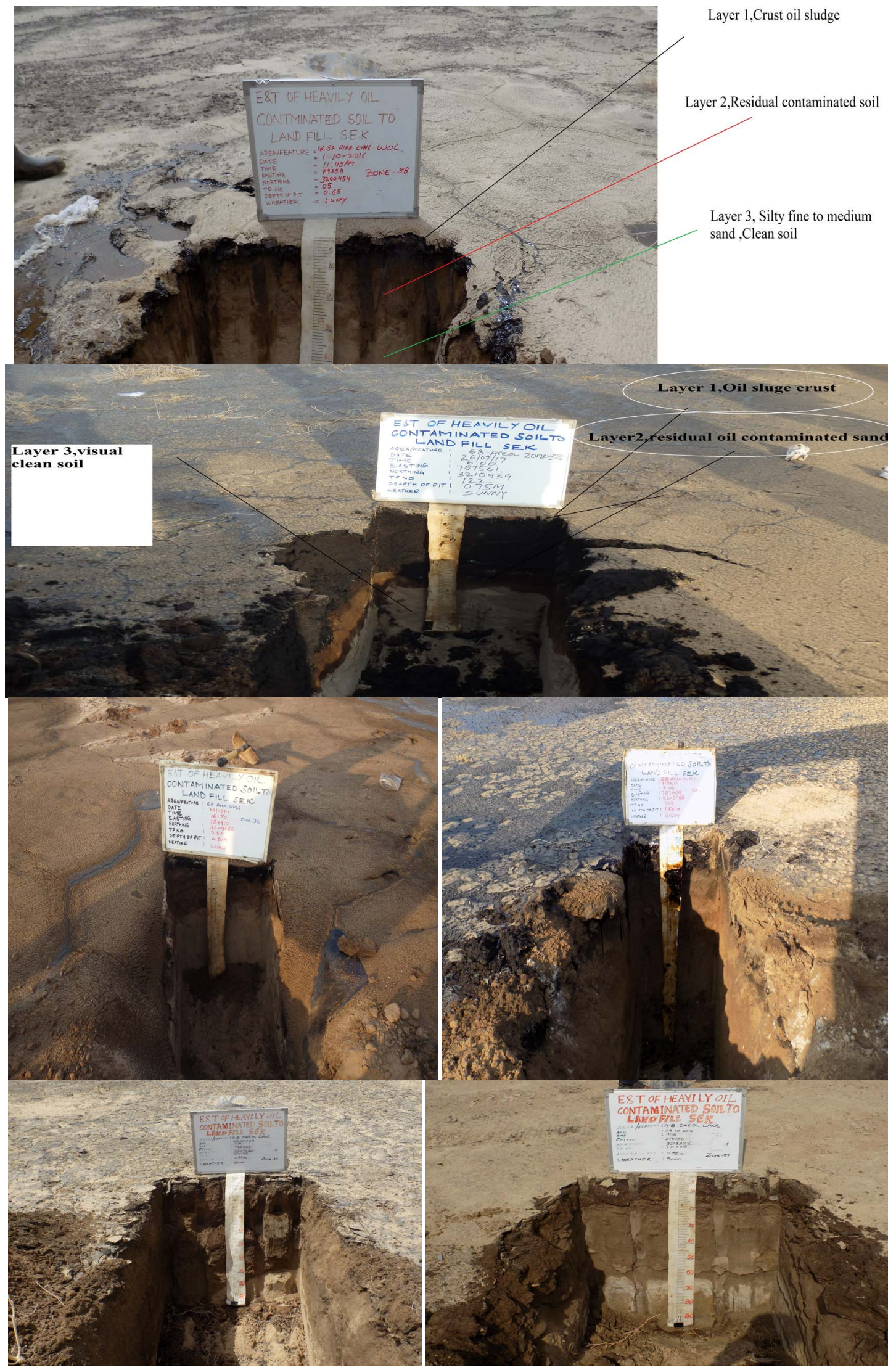

Figure 17. Soil profiles in area of study in GC32 PL dry oil lake and wet oil lake. 


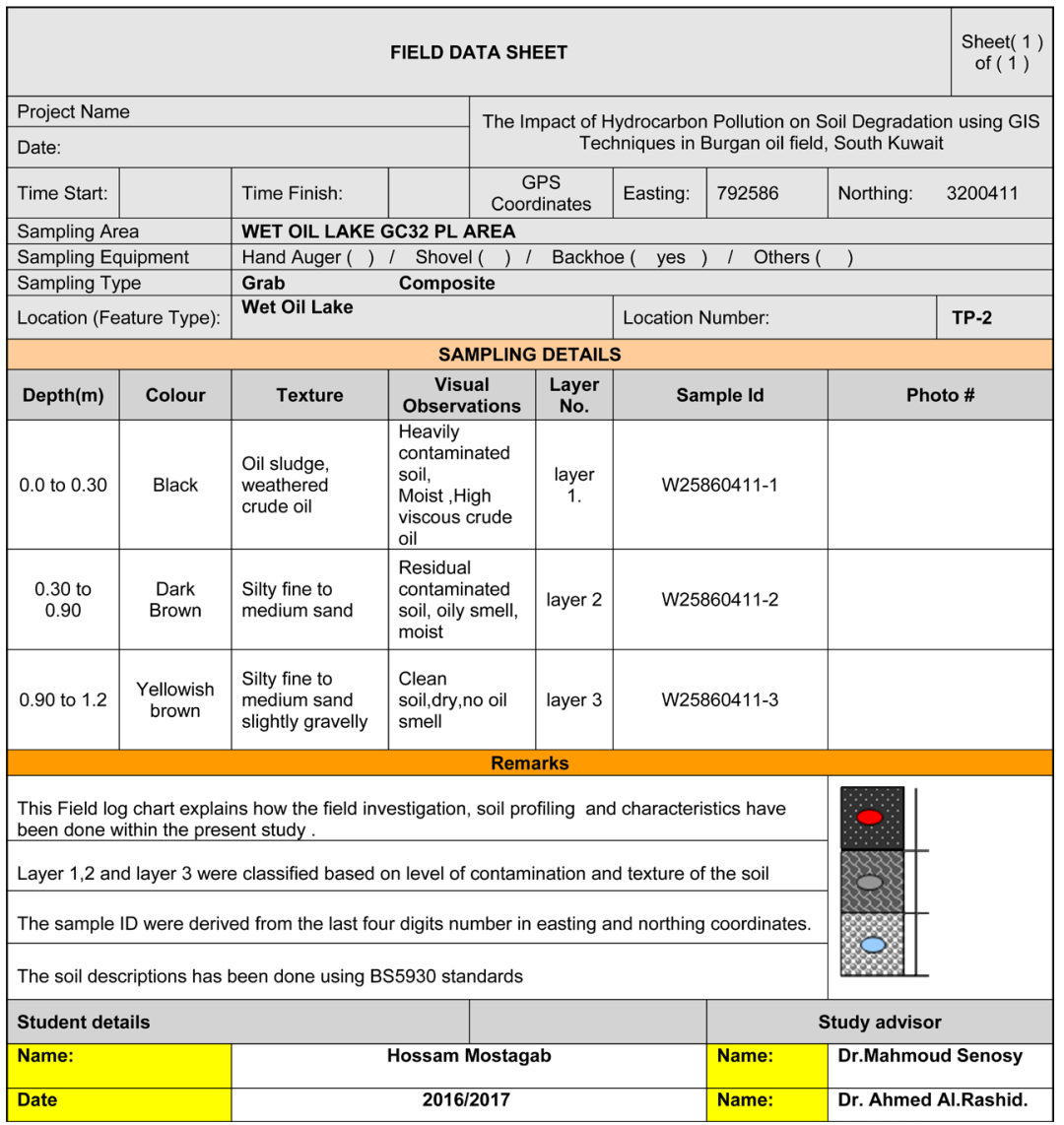

Figure 18. Sample for the field data sheet to profile oil contamination during site investigation.

lake areas then in wet oil lake areas, and oily soil is the dominant contaminated soil layer type.

\section{Acknowledgements}

I would first like to thank my thesis advisors Prof. Mahmoud Senosy, Dr. Ahmed Al-Rashid and Prof. Mahmoud Essa who suggested critical modification to the manuscript for making it more useful and for assisting in the interpretation of this critical study, the door to Prof. Imbarak S. Hassan (Suez Canal Univ, Egypt) office was always open whenever I ran into a trouble spot or had a question about my research or writing.

The authors would like also to thank Kuwait Oil Company (KOC) authority, Alghanim International General Trading Company, Kuwait. I am using this opportunity to express my gratitude to everyone who supported me throughout the course of this study, I am thankful for their aspiring guidance, invaluably constructive criticism and friendly advice during the project work.

\section{References}

[1] Ud Din, S., Al Dousari, A. and Literathy, P. (2006) Evidence of Hydrocarbon Contamination from the Burgan Oil Field, Kuwait-Interpretations from Thermal Re- 
mote Sensing Data Kuwait Institute for Scientific Research.

[2] Omar, S., Grealish, G. and Roy, W. (2006) Types and Extent of Soil Contamination in Greater Al-Burgan Oil Field, Kuwait. Kuwait Journal of Science and Engineering, 33, 89-99.

[3] Kwarteng, A.Y. and Al-Ajmi, D. (1997) Satellite Remote Sensing Applications in the State of Kuwait. Kuwait Institute for Scientific Research, Kuwait, 101 p.

[4] Al-Gharabally, D. and Al-Barood, A. (2015) Kuwait Environmental Remediation Program (KERP) Remediation Demonstration Strategy. Biological and Chemical Research, 2015, 289-296.

[5] (2015) A Picture of a Dead Bird in One of the Oil Lakes. https://www.pinterest.com/pin/burninginKuwaitwells

[6] Site Soil Characterization Report in South East Kuwait (2016) Alghanim International Company Soil Remediation Team 2. Excavation and Transportation of the Heavily Contaminated Soil in South East Kuwait landfill Project, KERP, Kuwait.

[7] Al-Sulaimi, J., Viswanathan, M.N. and Szekely, F. (1993) Effect of Oil Pollution on Fresh Groundwater in Kuwait. Environmental Geology, 22, 246-256. https://doi.org/10.1007/BF00767410

[8] Zaman, S. and Alsdirawi, F. (1993) Assessment of the Gulf Environmental Crisis Impacts on Kuwait's Desert Renewable Natural Resources. Kuwait Institute for Scientific Research, Report No. KISR 4247, Kuwait.

[9] Balba, M.T., Al-Daher, R., Al-Awadhi, N., Chino, H. and Tsuji, H. (1998) Bioremediation of Oil Contaminated Desert Soil: The Kuwaiti Experience. Environment International, 24, 163-173. https://doi.org/10.1016/S0160-4120(97)00132-3

[10] Al-Ajmi, D., Misak, R., Khalaf, F.I., Al-Sudairawi, M. and Al-Dousari, A.M. (1994) Damage Assessment of the Desert and Coastal Environment of Kuwait by Remote Sensing (VT001C). Report No. KISR 4405, Kuwait Institute for Scientific Research, Kuwait.

[11] Kwarteng, A.Y. (1998) Multi Temporal Remote Sensing Data Analysis of Kuwait's Oil Lakes. Environment International, 2, 121-137. https://doi.org/10.1016/S0160-4120(97)00129-3

[12] Kwarteng, A.Y. (1999) Remote Sensing Assessment of Oil Lakes and Oil Polluted Surfaces at the Greater Burgan Oil Field, Kuwait. International Journal of Applied Earth Observation and Geo Information, 1, 36-47. https://doi.org/10.1016/S0303-2434(99)85026-0

[13] (2018) Largest Oil Spills in History. https://www.telegraph.co.uk/news/worldnews/australiaandthepacific/newzealand/8 812598/10-largest-oil-spills-in-history.html

[14] Khalaf, F.I., Gharib, I.M. and Al-Hashash, M.Z. (1984) Types and Characteristics of the Recent Surface Deposits of Kuwait, Arabian Gulf. Journal of Arid Environments, 7, 9-33.

[15] Owen, R.M.S. and Nasr, S.N. (1958) Stratigraphy of the Kuwait-Basra Area. In: Weeks, L.G., Ed., Habitat of Oil a Symposium, Am. Assoc. Petroleum Geologists, Tulsa, 1252-1278.

[16] Al-Ruwaih, F.M. (1992) The Feasibility of Resistivity Sounding Method for Detecting the Saline/Brackish Water Interface in Kuwait. Kuwait Journal of Science and Engineering, 19, 1-8.

[17] Soil Survey Division Staff (1993) Soil Survey Manual. United States Department of Agriculture, Handbook No. 18, Government Printing Office, Washington DC. 